\title{
疲労クラック近くにおける下部組織の $\mathrm{X}$ 線的観察
}

\section{辛島誠一*及川洪* 小倉次夫**}

Seiichi Karashima, Hiroshi Oikawa and Tsugio Ogura : Studies on the Substructure Developed around Fatigue Cracks. The substructure formation around fatigue cracks in $\alpha$-brass, copper and aluminium was studied by means of X-ray microbeam technique, in order to make clear the relation bətween substructure and fatigue crack propagation.

The rejalts obtained were as follows: (1) There exist plastic zones in the vicinity of fatigue cracks in all the cases. (2) In $\alpha$-brass subgrains were formed only with in the plastic zone, whereas in copper and aluminium grains were divided into smaller subgrains in the zone than in the matrix. (3) The substructure became pronounced as the stacking fault energy increased. (4) In aluminium, fatigue cracks propagated more quickly in the specimen with a more developed substructure.

From the experimental results, it is concluded that the substructure formation is not only an incidental phenomenon but plays an important role in the mechanism of fatigue crack propagation.

(Received December 16, 1966)

\section{I. 緒 言}

疲労機構に関するこれまでの多くの研究によると, 疲労 クラックは疲労過程のきわめて初期に発生しており, 疲労 寿命の大部分は疲労クラック伝播のために費やされる(1). したがつて疲労クラック伝播の機構を解明することは, 疲 労の研究に拈ける重要な問題の一つと考觉られる.この問 題に関する組織学的研究は, 従来主としてアルミニウムに ついて行なわれて括り, 疲労変形によつて形成される下部 組織と疲労クラック伝播の機構との間に密接な関連がある らしいことが明らかにされている。すすおち，Holden(2)は 副結晶粒界 (sub-boundary) 飞生じた多数のミクロクラッ クが連結することによつて疲労クラックが伝播するとして いる.また Grosskreutz ${ }^{(3)}$, Backofen ${ }^{(4)}$ は副結晶粒界が疲労 クラック伝播のための優先的な経路になるとしている。一 方 McEvily ${ }^{(5)}$ は副結晶粒界そのものが分離, 破壊するので はなく，硬化した副結晶粒界部と柔らかい地との界面に沿 つて，破断が扣こるだろうとしている.

しかし現在までのところ, 疲労クラック伝播の機構と下 部組織形成との関係を示寸確実な実験的根拠は見出されて いない(6). 本実験では, 疲労クラック伝播の機構に括ける 下部組織の役割についての基礎的な知見を得る目的で, 積

* 東北大学工学部金属材料工学科 (Department of Materials Science, Faculty of Engineering, Tohoku University, Sendai)

** 東北大学大学院 (Graduate Student, Tohoku University, Sendai)

（1）たとえば,E.R.Rarker and D.M.Fegredo: Internal Stress and Fatigue in Metals, (Elsevier Publ., 1959), p. 263 .

(2) J.Holdn: Phil.Mag., 6 (1961), 547.

(3) J. C. Grosskreutz and P. Waldow: Acta Met., 11 (1963), 717 .

(4) D.H. Avery and W.A. Backofen: Fracture of Solids, (Interscience Publ., 1962), p.339.

(5) A.J.McEvily Jr.and R.C. Boettner: Acta Met., 11 (1963) ,725.

(6) N.E.Frost: Preprint of International Conference on Fracture, (1965), DI-3.
層欠陥エネルギーの異なる二三の $f c c$ 金属および合金につ いて, その疲労クラック近くの下部組織をX線的に観察し た.ここではその結果について述べる.

\section{II. 実 験 方 法}

試料素材は電解銅地金を真空溶解 した銅, 電解銅地金 と，高純度亜鉛地金とを大気中溶製した $\alpha$-黄銅 $(30 \mathrm{wt} \%$ Zn)，拉よび高純度アルミニウム地金を大気中溶解したア ルミニウムである.これらの素材を最終的に $0.2 \mathrm{~mm}$ まで 冷間圧延し，この圧延板から Fig.1に示したような試験

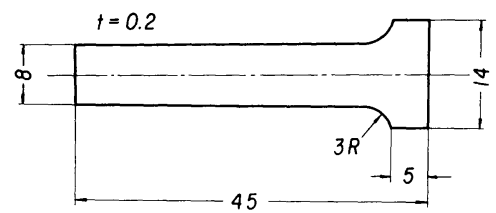

Fig.1 Fatigue specimen. (dimensions in $\mathrm{mm}$ )

片を切り出し，完全に焼鈍した後疲労試験を行なつた。な 技焼鈍条件は $\alpha$-黄銅，銅，アルミニウムに対してそれぞ れ $450^{\circ} \mathrm{C} 2$ 時間 (アルゴンガス中), $350^{\circ} \mathrm{C} 3$ 時間 (真空中) $300^{\circ} \mathrm{C} 5$ 分 (大気中) である. 使用した疲労試験機は自家製 の共振型交番曲 げ疲労試験機 (7) (共振周波数 300 500 c.p.s.) で, これにより, ゲージ部幅の約 $1 / 2$ の長さのクラ ックを作りこのようなクラックの周辺についてX線的な 観察を行なつた.

下部組織の $X$ 線的観察には細束 $X$ 線法 ${ }^{(8)}$ (10)を用いた. これによると, 副結晶粒の平均の体積 $V$ は次式から求めら

(7) S. Karashima and M. Takamura : Tech. Rep. Tohoku Univ., 26 (1962), 85.

(8) P. B. Hirsch and J.N. Kellar: Proc. Phys. Soc., 64 (1951) , 369 .

(9) P.B.Hirsch and J.N.Kellar: Acta cryst., 5 (1952), 162 .

(10) P.Gay and A.Kelly: ibid, 6 (1953), 165. 
れる。

$$
\bar{v}=\frac{1}{2} p\left(\frac{V}{N}\right) \cos \theta(d \theta+\Delta)
$$

ここに, $p:$ 多重度因子, $V: X$ 線ビームの試料照射体 積, $N$ : 注目するデパイ環に含まれる微細斑点の総数, $\theta$ : ブラッグ角, $d \theta: \mathrm{X}$ 線ビームの開き角, $\Delta:$ 副結晶粒のひ ずみ，大きさ，扣上び特性X線の波長の広がりに由来する 因子である，ただし本実験で得られた写真の中には，同一 のデバイ環内にもとの回折斑点が分裂してできたものと， 分裂しない回折斑点とが共存しているものがあつた．この 場合これらの斑点は平等には数元られないので，分裂しな い斑点も分裂した斑点と同じ割合で分裂していると仮定 ᄂて,

$$
N^{\prime}=(a+b) \frac{\Sigma n_{j}}{b}
$$

によつて与兄れる $N^{\prime}$ を(1)式の $N$ の代りに用いた。 こ こに， $a$ : 分裂しないデバイ斑点の総数， $b$ : 分裂したデバ イ斑点の総数， $n_{j}$ : 分裂したデバイ斑点 $j$ 内に含まれる微 細斑点の総数である。

つぎに, 疲労変形によつて, 結晶粒内湢副結晶粒が形成 されると，副結晶粒内拉よび副結晶粒界に和ける転位の種 類とその分布のしかたなぞに応じて，副結晶粒内には格子 の彎曲あるいはねじれが生ずる，また副結晶粒界では格子 の折れあるいは称じれが生し，隣接する副結晶粒界に方位 差ができる。これらをそれぞれ副結晶粒内の方位差 (misorientation) $\alpha$ ，怙よび副結晶粒界での方位差 (disorientation) 的する，またその結果，むとの結晶粒内にはその中含 まれる副結晶粒による方位差が生ずる。この量を結晶粒内 の全方位差 (total misorientation) $\alpha_{\text {Total }}$ とする.これら $\alpha$, 牤よび $\alpha_{\text {Total }}$ は，それぞれ微細斑点の接線方向の広がり， 扣よび回折斑点の接線方向の広がりから計算することがで き，また $\beta$ は次式によつて計算できる。

$$
\beta=\beta^{\prime}-\alpha
$$

ここに, $\beta^{\prime}$ は隣接する副結晶粒界の方位差であり，これ は隣接する微細斑点の中心間の距離から計算でさる。

本実験では透過法を用い，CuK $\alpha_{1}$ 線による $\{111\}$ 反射の

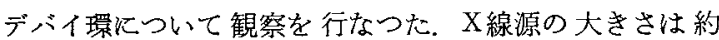
$40 \times 80 \mu^{c}, d \theta \approx 1^{\prime}, \mathrm{X}$ 線ビームの直径は試料面上で約 200

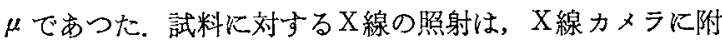
属寸る㩆微鏡によつて，營光板上のX線ビームの位置を確 認しここに試料の望久の部分をるつてくることによつて 行なわれた。な打本実験に打いては，透過法を採用したの でこの操作によつて確実に望みの部分にX線が照射され ているすのと考光られる．使用したX線発生装置は島津分 析用X線発生装置 MDX-2 型である。

\section{III. 結 果および考察}

Fig.2 は本実験において得られた $\alpha$-黄銅，銅，およびて ルミニウムの S-N 曲線である. 図内に矢印で示したよ5 にそれれぞれの金属について 3 本の陚料をX線観察に供し
た。 ただし、アルミニウムの場合に No.3の疲労寿命が異 常に短いのは，この試料には切欠きをつけて疲労試験を行
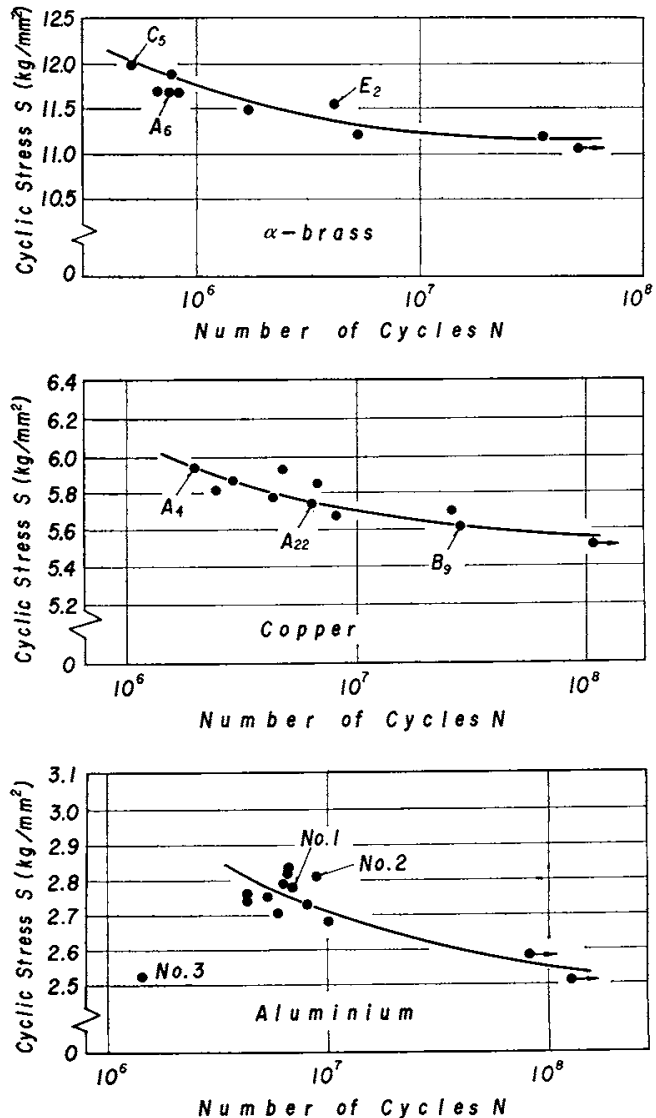

Fig.2 S-N curves of annealed $\alpha$-brass, copper and aluminium specimen.

(a)

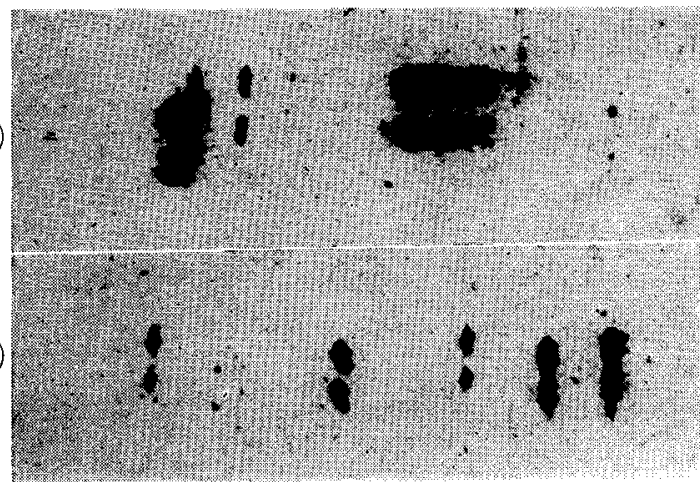

Photo.1 X-ray microbeam photographs obtained on $\alpha$-brass.

(a) taken at the tip of main crack.

(b) taken at matrix.

なつたからである。

Photo. 1 (a) , (b) は $\alpha$-黄銅の細束 X線写真の一部を拡大

したものを示す．(a)はクラック先端，(b)はクラック先端 から十分離れて叔り，先端からの応力集中の影響が無視で きると考えられる領域(以後ここをマトリックスと呼ぶ加 ら得たものである。これらの写真から明らかなように， 
ラック先端からの回折斑点の中には接線方向に広がつたも のがあり,このような斑点はさらに微細な斑点に分裂して いる. したがつて, $\alpha$-黄銅の疲労クラック先端には明ら かに下部組織が存在することが結論される. その特性は $\sqrt[3]{\bar{v}} \simeq 2.8 \mu, \alpha \simeq 19^{\prime}, \beta \simeq 4^{\prime}, \alpha_{\text {Total }} \simeq 1.2^{\circ}$ である. ᄂ かし、マトリックスからは下部組織を検出でさなかつた。

Fig.3 は $\alpha$-黄銅の疲労クラック近くおよびマトリック

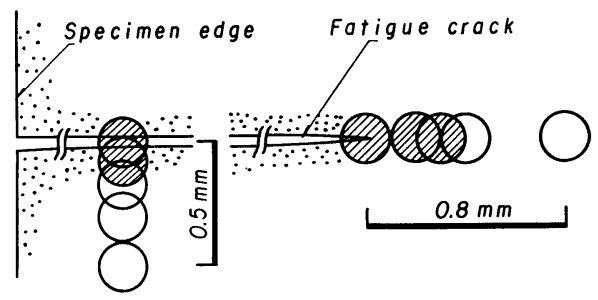

Fig. 3 Irradiated spots in $\alpha$-brass specimen $\left(\mathrm{A}_{6}\right)$.

: spots where substructure was detected.

$O$ : spots where substructure was not detected.

スでX線ビームの照射を受けた位置と，そこに拉ける下部 組織の有無とを示したものである，この図から明らかなよ 5 に, 疲労変形した $\alpha$-黄銅における下部組織の存在はク ラック近くに限られていることがわかつた. つまり $\alpha$-黄 銅の疲労クラック近くには下部組織が存在するという意味 で, いわゆる塑性域(11) (plastic zone) が存在することがわ かる. Fig.3 から明らかなよ5に，塑性域の大ささはクラ ック先端からクラック伝播方向に約 $0.3 \mathrm{~mm}$ である. しか しクラック破面からの深さは極めて小さく, $0.1 \mathrm{~mm}$ 以下 になつていると予想される. この場合 Fig.4(a)に示した

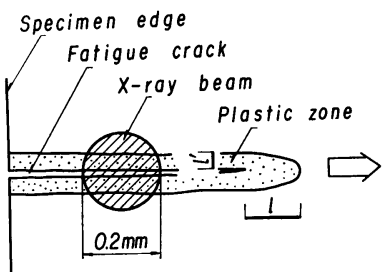

(a)

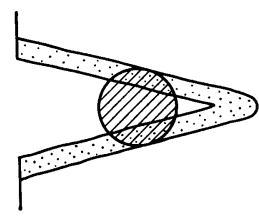

(b)
Fig.4 Method of estimating the size of plastic zone.

ように,たとえクラックの真上から $0.2 \mathrm{~mm}$ 径の X 線ビー ムを照射したとしても，X線ビームは塑性域全体を覆うこ とがでさない，そこで本実験では，Fig.4(b)に示したよ5 に,クラックの両破面を多少開き，X線ビームが塑性域全

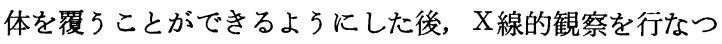
てみた. その結果, その前後のデバイ環には明らかな変化 があり，たとえば(2) 式におけるb/ $(a+b)$ の值*が著しく

(11) たとえば, N.E. Frost and D.S. Dugdale: J.Mech. Phys. Solids, 6 (1958) ,92.

* $a$ は試料の X線ビーム照射体積中に存在する下部組 織を含をない結晶粒の数に対応し, $b$ は下部組織を 含む結晶粒の数に対応する.したがつて，b/ $(a+b)$ はX線ビーム照射体積中において，下部組織を含む 結晶粒が存在する割合を表わす。
増加するのが認められた．このことから，塑性域のクラッ ク破面からの深さは＜0.1mm であると推定される.

(a)

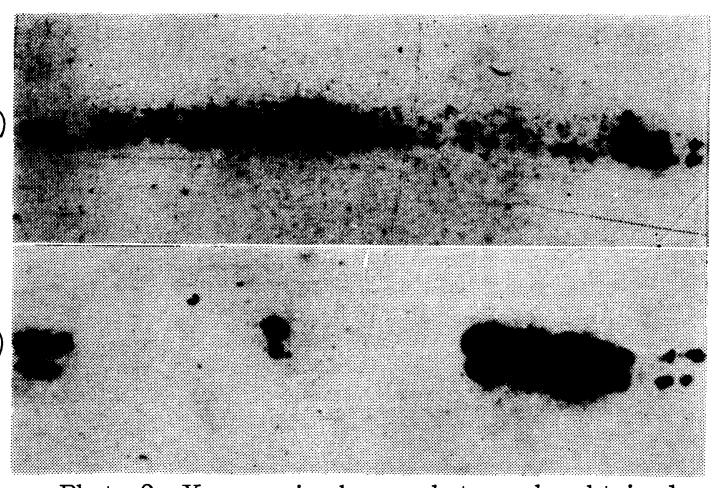

Photo.2 X-ray microbeam photographs obtained on copper.

(a) taken at the tip of main crack.

(b) taken at matrix.

Photo.2 (a) , (b) は銅の細束 X線写真の一例である. (a) はクラック先端，(b)はマトリックスから得たデバイ環の 一部を拡大したものである. これらの写真から明らかなよ ろに, 銅の場合, 下部組織の存在はクラック近くのみに限 られない. しかし，クラック近くに持ける下部組織の特性 の変化をみると，Fig.5(a)，(b)から明らかなよ5に，到

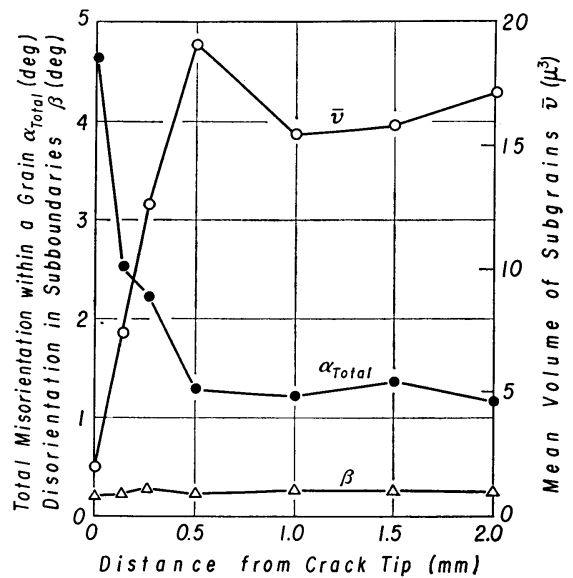

(a)

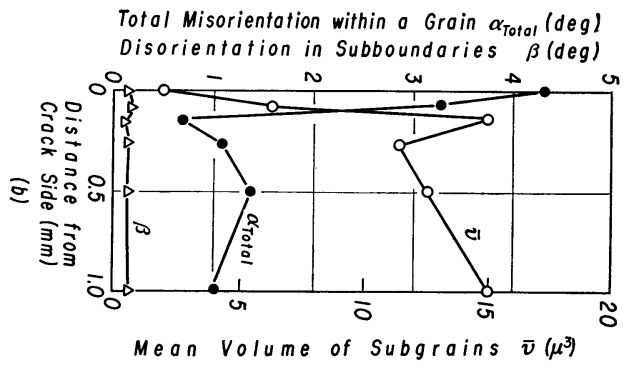

Fig.5 Change in some characters of substructure with distance. (a) from crack tip and (b) from crack side (copper).

クラック近くのある位置から急激に減少し, これに対応し て $\alpha_{\text {Total }}$ は急激に増加している.一方, $\beta$ 执よび $\alpha(\beta$ と同 
じ程度の值をとるので図には示してないははぼー定であ る、これから，銅の疲労クラック近くでは副結晶粒が著し

(a)

(b)

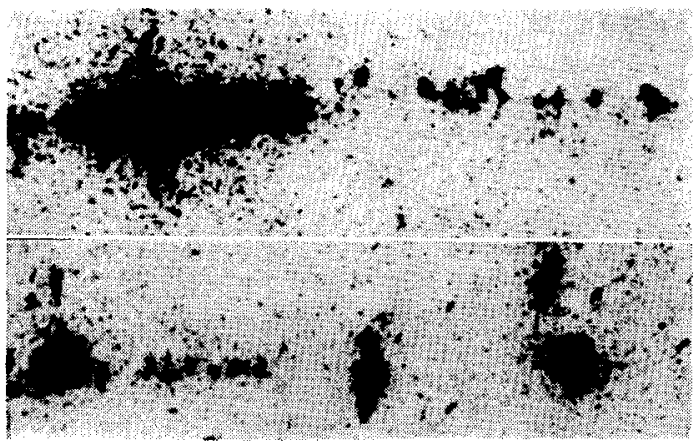

Photo.3 X-ray microbeam photographs obtained on aluminium.

(a) taken at the tip of main crack

(b) taken at matrix.

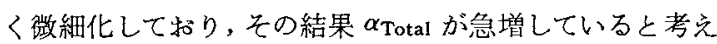
られる。このよ5な意味で，銅の疲労クラック近くにも望 性域が存在すると結論でさる.Fig.5(a)に示した $\alpha_{\text {Total }}$ たは $\vec{v} の$ 変化からみて，この場合の塑性域の大きさは，ク ラック先端からその進行方向に約 $0.2 \mathrm{~mm}$ と推定される. またクラック破面からの深さは $\alpha$-黄銅の場合と同様に にFig.4に示した方法に上つて<0.1 mm と推定された.

アルミニウムについての同様な結果をPhoto.3(a), (b) ;

Fig.6(a), (b) 飞示す. これからアルミニゥムの場合も, クラック先端にもマトリックスにも下部組織が存在してお

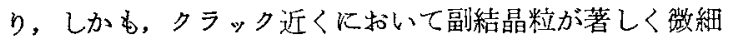
化していることが明らかである。この意味において，アル ミニウムの疲労クラック近くにもまた塑性域が存在すると 考壳られる。

Table 1 は以上のX線的観察結果をむ之めたものであ る.まず， $\alpha$-黄銅，銅执よびアルミニウムの疲労クラック 近くに存在する望性域(Fig.4)の大きさは，この領域の疲 労クラック先端からの長さl, 扎よ゙クラック破面からの 深さ $l^{\prime}$ とて示されているが，アルミニウムの場合に塑
$>D_{\alpha}(\mathrm{Al}) ; \beta(\alpha$-brass $)<\beta(\mathrm{CH})<\beta(\mathrm{Al}) ; \alpha_{\text {Total }}(\alpha$-brass $)$ $\left\langle\alpha_{\text {Total }}(\mathrm{Cu})<\alpha_{\text {Total }}(\mathrm{Al}) ;\right.$ ；でる，これから，下部組織形

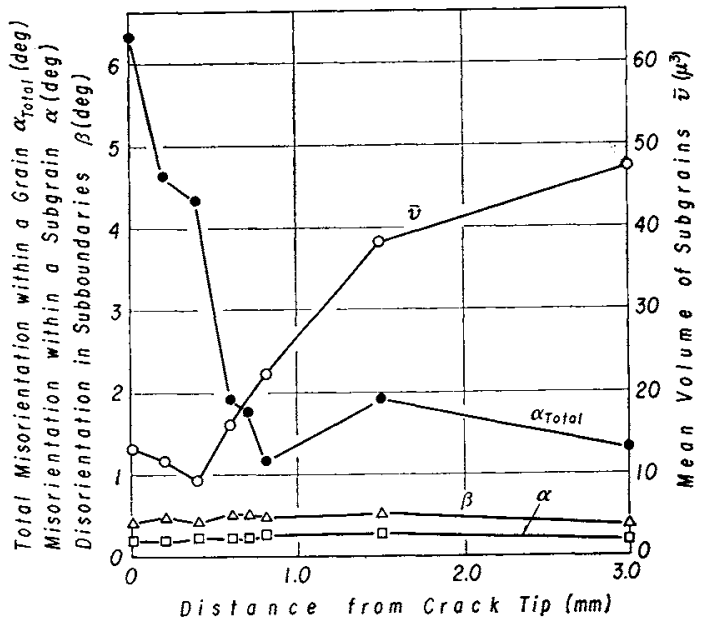

(a)

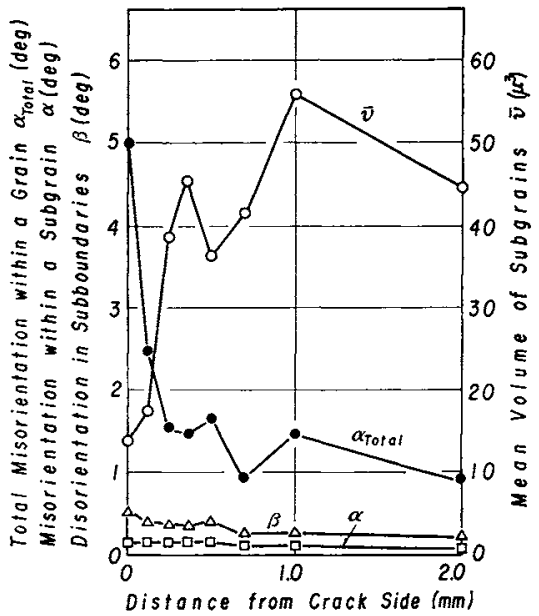

(b)

Fig.6 Change in some characters of substructure with distance. (a) from crack tip and (b) from crack side (aluminium).

Table 1 The results of X-ray observations at crack tip and in matrix.

( $T$ : crack tip, $M$ : matrix)

\begin{tabular}{|c|c|c|c|c|c|c|c|c|c|c|c|c|c|c|c|}
\hline & & \multicolumn{2}{|c|}{$\begin{array}{c}\text { Existence (yes) or } \\
\text { nonexistence (no) } \\
\text { of substructure }\end{array}$} & \multicolumn{2}{|c|}{$\sqrt[3]{\bar{v}}(\mu)$} & \multicolumn{2}{|c|}{$\alpha(\min )$} & \multicolumn{2}{|c|}{$D_{\alpha}\left(10^{8} / \mathrm{cm}^{2}\right)$} & \multicolumn{2}{|c|}{$\beta(\mathrm{min})$} & \multicolumn{2}{|c|}{$\alpha_{\text {Total }}(\mathrm{deg})$} & \multicolumn{2}{|c|}{ Size of plastic zone } \\
\hline & & $\mathrm{T}$ & M & $\mathrm{T}$ & $\mathrm{M}$ & $\mathrm{T}$ & $\mathrm{M}$ & $\mathrm{T}$ & M & $\mathrm{T}$ & $\mathrm{M}$ & $\mathrm{T}$ & $\mathrm{M}$ & $l(\mathrm{~mm})$ & $l^{\prime}(\mathrm{mm})$ \\
\hline \multicolumn{2}{|c|}{$\alpha$-brass } & yes & no & 2.8 & - & 19 & 一 & 7.2 & 一 & 4 & - & 1.2 & 一 & 0.3 & $<0.1$ \\
\hline \multicolumn{2}{|c|}{ Copper } & yes & yes & 1.4 & 2.5 & 8 & 11 & 6.8 & 5.0 & 8 & 7 & 4.7 & 1.3 & 0.2 & $<0.1$ \\
\hline 莺寻 & $\begin{array}{l}\text { No.1 } \\
\text { No. } 2 \\
\text { No. } 3\end{array}$ & $\begin{array}{l}\text { yes } \\
\text { yes } \\
\text { yes }\end{array}$ & $\begin{array}{l}\text { yes } \\
\text { yes } \\
\text { yes }\end{array}$ & $\begin{array}{l}2.5 \\
2.6 \\
2.6\end{array}$ & $\begin{array}{l}4.0 \\
3.1 \\
4.0\end{array}$ & $\begin{array}{l}8 \\
9 \\
8\end{array}$ & $\begin{array}{l}8 \\
9 \\
9\end{array}$ & $\begin{array}{l}3.3 \\
3.5 \\
3.2\end{array}$ & $\begin{array}{l}2.0 \\
3.0 \\
2.3\end{array}$ & $\begin{array}{l}20 \\
15 \\
18\end{array}$ & $\begin{array}{l}12 \\
13 \\
16\end{array}$ & $\begin{array}{l}6.3 \\
9.3 \\
5.1\end{array}$ & $\begin{array}{l}1.4 \\
3.7 \\
1.2\end{array}$ & $\begin{array}{l}0.5 \\
1.0 \\
0.5\end{array}$ & $\begin{array}{l}0.1 \\
0.2 \\
0.2\end{array}$ \\
\hline
\end{tabular}

性域はとくに大きいことがわかる。

つぎに，クラック先端，およびマトリックスに就る下 部組織の 特性を比較してみると， $D_{\alpha}(\alpha$-brass $)>D_{\alpha}(\mathrm{Cu})$
成の明瞭さは $\mathrm{Al}>\mathrm{Cu}>\boldsymbol{\alpha}$-brass $の$ 順，つまり積層欠陌 エネルギーの大きい順序になつていることがわかる。この よ 5 に, 積層欠阫エネルギーの大きいほど下部組織の発達 
が著しいといらことは，静的変形した $f c c$ 金属に関する， これまでの多くの観察(12)と一致している.

(a)

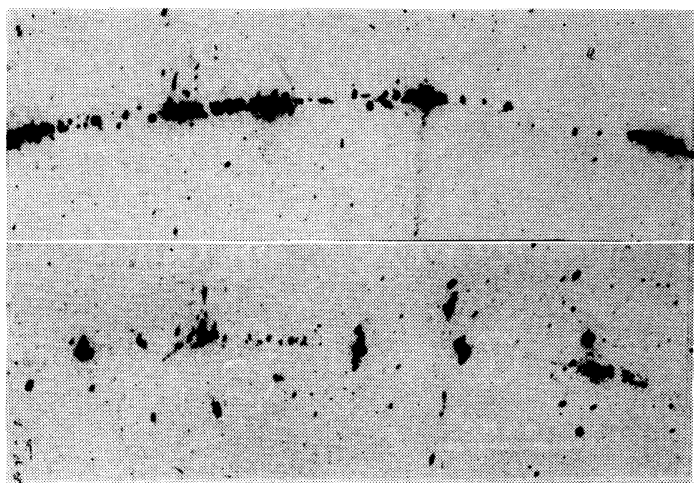

Photo.4 X-ray microbeam photographs taken at matrices of two aluminium specimens.

(a) No.2 and (b) No.3.

(a)

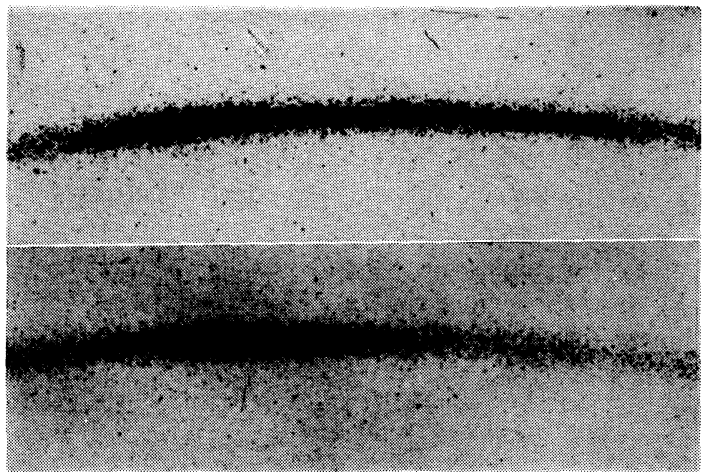

Photo.5 X-ray microbeam photographs obtained on statically deformed $\alpha$-brass.

(a) taken at the tip of main crack.

(b) taken at matrix.

また， 3 本のアルミニウム試料のうち，切欠きをつけて 疲労試験を行なつた結果, とくにクラック伝播速度がゆる やかであつた試料 No.3 と，とくにクラック伝播速度が急 速であつた切欠きのない試料 No. 2 との, マトリックスに 拈ける下部組織に注目してみる.Photo.4(a)，(b)はそれぞ れ試料 No.2, No.3 のマトリックスに拈ける細束 X線写真 の一部を示す.この図から明らかなよ5に, 下部組織の発 達は試料 No. 2 における方が大である(Table 1 参照).

このように, マトリックスに拈ける下部組織の発達が著 しい試料中を, 疲労クラックがより速く伝播するというこ とは, 下部組織の形成が, 疲労クラック伝播の結果の単な る附随現象でないことを示するのであろ5。

本実験では比較のため, 引張りクラック近くについて も，細束X線による観察を行なつた. Photo.5 (a), (b) ; Photo.6 (a)，(b) 扎よび Photo.7 (a)，(b) はそれぞれ $\alpha$-黄 銅, 銅およびアルミニウムの，(a)引張りクラック先端, (b) マトリックスに拈ける細束 X線写真の一例を示す。 こ

(12) P.R. Swann: Electron Microscopy and Strength of Crystals, (Interscience Publ., 1962), p.131.
れらの写真から明らかなように, $\alpha$-黄銅の場合, 副結晶粒 は引張りクラック先端に括いてさえも形成されず, 銅とア

(a)

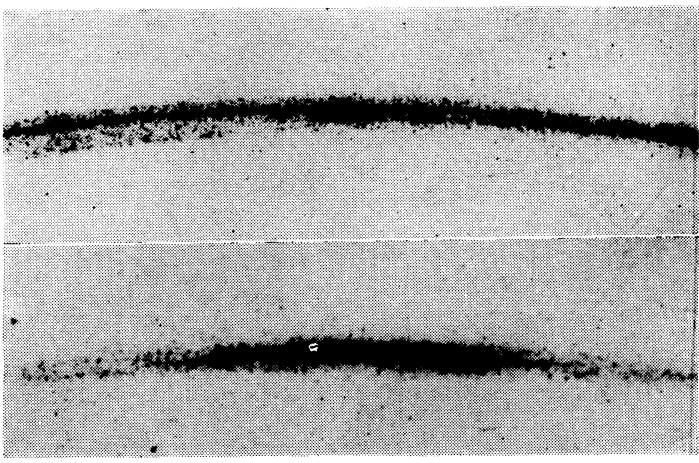

Photo. 6 X-ray microbeam photographs obtained on statically deformed copper.

(a) taken at the tip of main crack.

(b) taken at matrix.

(a)

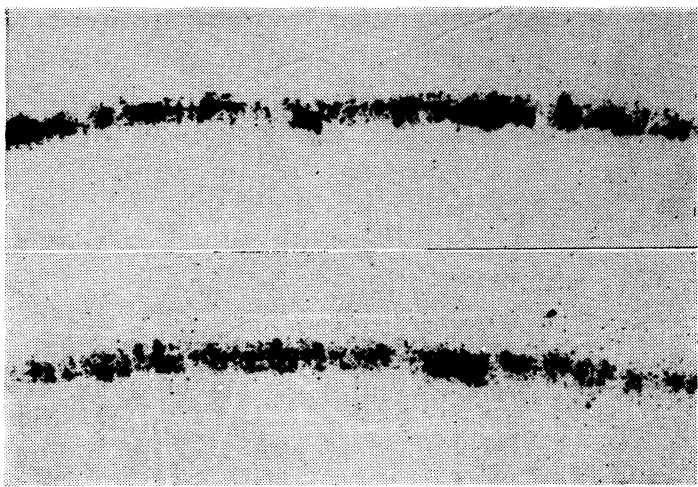

Photo.7 X-ray microbeam photographs obtained on statically deformed aluminium.

(a) taken at the tip of main crack.

(b) taken at matrix.

ルミニウムの場合，下部組織形成は疲労クラック近くほど 明瞭でない。 また，引張りクラック先端とマトリックスと で, 下部組織形成の明瞭さに括ける差異はない.

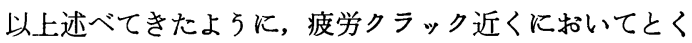
に明瞭な下部組織の形成されることは, 疲労ク $ッ ク$ 伝播 の機構における下部組織形成の重要性を示唆するものであ ろ5.

\section{IV. 結 論}

$\alpha$-黄銅, 銅およびアルミニウムの疲労クラック近くにお ける下部組織をX線的に観察した結果, つぎの事実が明ら かになつた.

(1) いずれの金属, および合金においても, 疲労クラッ ク近くにはマトリックスと異なつた塑性域が存在し， $\alpha$-黄 銅に拈いては, この塑性域内にのみ下部組織が形成され， 銅およびアルミニウムに括いては, この塑性域内で副結晶 粒の著しい微細化が扣こる。

（2）塑性域の大きさはアルミニウムの場合にとくに大 
きい.

(3) 塑性域内の下部組織の特性は, 副結晶粒径について 又ると， $\alpha$-黄銅の場合約 $2.8 \mu$, 銅の場合約 $1.4 \mu, 7 ル$ ミ

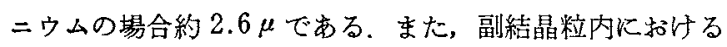
方位差 $\alpha$, 副結晶粒界における方位差 $\beta$, 全方位差 $\alpha_{\text {Total }}$ などを比較すると，下部組織形成の明瞭さは，フルミニウ 厶，銅， $\alpha$-黄銅の頪，つまり積噟欠陷エネルギーの大きい 順序になつている。
(4) アルミニウムにおいては, 、トリックスにおける下 部組織発達の著しい試料中を疲労クラックがより急速に伝 播することが明らかになつた。

(5) 以上の結果から，下部組織形成が疲労クラック伝播 に重要な役割りを果たすものと考えられる。

本実験遂行にあたり，御協力を賜わつた金材技研，貝沼 紀夫氏，昭和電工，関 昇氏に深く感謝致します。 